Crowhurst R.N., Hawthorne B.T., RikKerink E.H. and Templeton M.D. : Differentiation of Fusarium solani f. sp. cucurbitae races 1 and 2 by random amplification of polymorphic DNA. Current Genet., 1991, 20, 391-396.

DukE B.O.L. : Geographical aspects of onchocerciasis. Ann. Soc. Belge Med. Trop., 1981, 61, 179-186.

Erttmann K.D., Unnasch T.R., Greene B.M., Albiez E.J., Boateng J., Denke A.M., Ferraroni J.J., Karam M., Schulz-Key H. and Williams P.N. : A DNA sequence specific for forest form Onchocerca volvulus. Nature, 1987, 327, 415-417.

Erttmann K.D., Meredith S.E.O., Greene B.M. and Unnasch T.R. Isolation and characterisation of form specific DNA sequences of O. volvulus. Acta Leidensia, 1990, 1-2, 253-260.

Feinberg A.P. and Volgetstein B. : A technique for radio labelling DNA restriction endonucleases fragments to high specific activity. Anal. Biochem., 1983, 137, 6-13.

Hadrys H., Balick M. and Schierwater B. : Applications of random amplified polymorphic DNA (RAPD) in molecular ecology. Mol. Ecol, 1992, 1, 55-63.

Hanahan D. : Studies on transformation of Escherichia coli with plasmids. J. Mol. Biol., 1983, 166, 557-580.

Hugues C.R. and Quelier D.C. : Detection of highly polymorphic microsatellite loci in a species with little allozyme polymorphism. Mol. Ecol., 1993, 2, 131-137.

Klein-Lankhorst R.M., Vermunt A., Weide R., Liharska T. and Zabel P. : Isolation of molecular markers for tomato (L. esculentum) using random amplified polymorphic DNA (RAPD). Theor. Appl. Genet., 1991, 83, 108-114.

LITT M. and LuTY J.A. : A hypervariable microsatellite revealed by in vitro amplification of a dinucleotide repeat within the cardiac muscle actin gene. Am.J. Hum. Genet., 1989, 44, 397-401.

Love J.M., Knight A.M., McAleer M.A. and Todd J.A. : Towards construction of a high resolution map of the mouse genome using PCR-analysed microsatellites. Nucl. Ac. Res., 1990, 18, $\mathrm{n}^{\circ} 14,4123-4130$.

Mazurier S., van de Giessen A., Heuvelman K. and Wernars K. : RAPD analysis of Campylobacter isolates : DNA fingerprinting without the need to purify DNA. Letters in Appl. Microbiol., 1992, 14, 260-262.

McMahon J.E., Davies J.B., White M.D., Goddard J.M., BeechGarwood P.A. and KirkwoOd B.R. : Onchocerciasis in Sierra Leone. I. Studies on the prevalence and transmission at Gbaima village. Trans. Roy. Soc. Trop. Med. Hyg., 1986, 80, 802-809.

Meredith S.E.O., Unnasch T.R., Karam M., Piessens W.F. and Wirth D.F. : Cloning and characterisation of an Onchocerca volvulus specific DNA sequence. Mol. Biochem. Parasitol., 1989, 36, 1-10.

Meredith S.E.O., Lando G., Gbakima A.A., Zimmerman P.A. and UNNASCH T.R. : Onchocerca volvulus : application of polymerase chain reaction to identification and strain differentiation of the parasite. Exp. Parasitol., 1991, 73, 335-344.

Messing J. : New M13 vectors for cloning. In Methods in Enzymology. Wu R., Grossman L. and Moldave K. (eds), New York, Academic Press, 1983, vol. 101, 10-89.

Prost A., Rougemont A. and Omar M.S. : Caractères épidémiologiques, cliniques et biologiques des onchocercoses de savane et de forêt en Afrique occidentale. Ann. Parasitol., 1980, 55, 347355.

Sanger F., Nicklen S. and Coulson A.R. : DNA sequencing with chain-terminating inhibitors. Proc. Natl. Acad. Sci., 1977, 74, 5463-5467.

Schulz-Key H., Albiez E.J., ButTner D.W. : Isolation of living adult Onchocerca volvulus from nodules. Tropenmed. Parasitol., 1977, 28, 428-430.

Swaiger F.W., Gomolka M., Geldermann H., Zischler H., Buttkamp J., EPplen J.T. and Ammer H. : Oligonucleotide fingerprinting to individualize ungulates. Appl. Theor. Electrophoresis, 1992, 2, 193 200.

TAuTz D. : Hypervariability of simple sequences as a general source for polymorphic DNA markers. Nucl. Ac. Res., 1989, 17, $\mathrm{n}^{\circ}$ 16, 6463-6471.

WEBER J.L. and MAY P.E. : Abundant class of human DNA polymorphisms which can be typed using the polymerase chain reaction. Am. J. Hum. Genet., 1989, 44, 388-396.

Welsh J. and MC Clelland M. : Fingerprinting genomes using PCR with arbitrary primers. Nucl. Ac. Res., 1990, 18, n 24, 7213-7218.

Welsh J., Petersen C. and Mc Clelland M. : Polymorphisms generated by arbitrarily primed PCR in the mouse : application to strain identification and genetic mapping. Nucl. Ac. Res., 1991, 19, $n^{\circ} 2,303-306$.

Williams J.G.K., Kubelik A.R., Livak K.J., Rafalski J.A. and Tingey S.V. : DNA polymorphisms amplified by arbitrary primers are useful as genetic markers. Nucl. Ac. Res., 1990, 19, n² 2, 303-306.

Zimmerman P.A., Dadzie K.Y., de Sole G., Remme J., Soumbey Alley E. and UNNASCH T.R. : Onchocerca volvulus DNA probe classification correlates with epidemiologic patterns of blindness. J. Inf. Diseases, 1992, 165, 964-968.

\section{CUTICLIN GENES OF NEMATODES}

LEWIS E.*, SEBASTIANO M.*, NOLA M.*, ZEI F.*, LASSANDRO

F. ${ }^{*}$, RISTORATORE F., ${ }^{*}$ CERMOLA M. ${ }^{*}$, FAVRE R.* AND

BAZZICALUPO P.*

KEYWORDS : parasitic nematodes, cuticle. cuticlin, dityrosine, cross-linking.

SUMMARY

Two genes coding for cuticlin components of Caenorhabditis elegans have been cloned and their structure is described. Recombinant proteins have been produced in E. coli and antibodies raised against them. Nucleic acid and specific antibodies are being used to isolate the homologues from the parasitic species Ascaris lumbricoides and Brugia pahangi.

The nematode cuticle protects the animal, serves as an exoskeleton and provides the surface over which interactions with the external environment occur. In the case of parasitic nematodes the external environment is the host and, as such, antigens expressed on/in the cuticle are within reach of both the humoral and cellular components of the immune system. The cuticle is a layered structure, the components of which are classified according to their solubility : lipids, some proteins and other readily soluble, non-structural components are mostly localized on the surface but are also distributed to a lesser extent throughout the lower layers of the cuticle ; the collagens make up the structural bulk of the cuticle, are coded for by a large and relatively well-characterized gene family, are not exposed on the cuticle surface and can be solubilized with SDS and mercaptoethanol ; and finally there is a highly cross-linked, insoluble and complex mixture of proteins present throughout the cuticle and known as the cuticlins. Up until now it has been virtually impossible to determine the roles and importance of the cuticlins because their insolubility does not allow either molecular or biochemical analysis of individual proteins.

* International Institute of Genetics and Biophysics, CNR, via G. Marconi 10, 80125 Napoli, Italy. 
However, two cuticlin genes, cut-1 and cut-2, have now been isolated from $C$. elegans in this laboratory, using a $D$. melanogaster probe coding for a component of the vitelline membrane of the egg. cut-1 mRNA is $1422 \mathrm{nt}$ long, has four exons coding for 423 amino acids and is transpliced to SL1, the spliced leader present at the 5' end of many mRNA's in most nematodes ; cut-2 mRNA is 847 nt long, contains only two exons coding for 237 amino acids, and is not transpliced. Northern analysis indicates that while cut -1 is transcribed stage-specifically by worms entering the dauer larvae stage, cut-2 mRNA is transcribed during cuticle synthesis, immediatly before each moult.

Parts of both genes have been expressed as fusion proteins in $E$. coli and have been used to raise specific antibodies. These have been used to study the expression pattern of the two genes by western blot, and to localize the products within the cuticles of worms at different stages by immunofluorescence and immuno-electron microscopy. The results obtained confirm the partial stage specifity of CUT-1, and the fact that CUT-2 is a component of the cuticle at all stages. Both proteins are localized on cuticle residues after treatment with strong reducing agents, showing them to be definitively members of the cuticlin residue.

The proteins deriving from the conceptual translation of the genes differ substantially, although they both begin with signal peptides and share a short motif repeated 5 times in CUT-1 and 12 times in CUT-2. Each repetition is characterized by the presence of the amino acid sequence AAPA. This same motif can also be found in some of the vitelline membrane proteins of Drosophila and in the proteins which make up the cuticle of Locusta migratoria. These proteins are all involved in the formation of insoluble, protective extracellular layers, implying that the conserved domains may have an important functional role.

Interestingly, the amino acid sequence of CUT-2 shows tyrosine residues that could participate in dityrosine bridge formation (dityrosine is present in the insoluble residue of parasitic nematode cuticles). We have shown that soluble recombinant CUT-2, produced in E. coli, can be polymerized in vitro into high molecular weight species by the action of $\mathrm{HR}$ peroxidase in the presence of $\mathrm{H}_{2} \mathrm{O}_{2}$. The products of the reaction become insoluble, contain tyrosine and the reaction is inhibited by the presence of free tyrosine. This clearly begs the question whether CUT-2 is responsible for the insolubility of the cuticle.

A second gene showing significant homology (> $80 \%$ ) to cut-1 has been isolated for C. elegans, confirming the possible existence of a cuticlin gene family. A cut-1 homologue has also been isolated from the plant parasitic nematode, Meloidogyne artiella, demonstrating the strongly conserved nature of the sequence amongst nematodes.

An insoluble cuticlin residue is present in the cuticles of all nematodes studied so far. This fact, plus the apparently conserved nature of the gene and the protein for which it codes, has prompted the search for genes homologous to cut-1 and cut-2 in two parasitic nematodes, Ascaris lumbricoides and Brugia pahangi.

Two parallel approaches have been used : the first involves screening a genomic library with labelled DNA probes made from $C$. elegans cuticlin genes; the second involves screening a parasite cDNA expression library with the spe- cific antibodies raised against the recombinant CUT-1 and CUT-2 purified proteins. The positive clones have been sub-cloned into the pBluescript phagemid system and are at present being sequenced. The sequences will be checked for homology against the $C$. elegans cuticlin genes and the Sequences Data Base.

Once cuticlin gene homologues have been found the approach to their study will follow two broad pathways. Firstly transcription patterns in the parasite life-cycles will be studied using reverse transcriptase and PCR. And secondly the inserts will be expressed and the resultant recombinant proteins used in biochemical and immunological studies. Antibodies could also be raised against these proteins for use in localization and time-course experiments, and hopefully to screen the cDNA libraries of other parasitic nematodes.

Once parasitic nematode homologues of cut-1 and cut-2 have been fully characterized, the roles and functions of these clearly important proteins will be better understood and hopefully the knowledge can in some way be used in the control of the diseases caused by these parasitic nematodes.

\section{REFERENCES}

Lassandro F., Sebastiano M., Zei F. and Bazzicalupo P. : cut-2, a second cuticlin gene of Caenorhabditis elegans. The role of dityrosine formation in the crosslinking of its product. Mol. Biochem. Parasitol., 1993, submitted.

Politz S.M. and Philipp M. : Caenorbabditis elegans as a model for parasitic nematodes : A focus on the cuticle. Parasitol. Today, 1992, 8, 6-12.

Sebastiano M., Lassandro F., Bazzicalupo P. : cut-1, a Caenorbabditis elegans gene coding for a dauer-specific non collagenous component of the cuticle. Dev. Biol., 1991, 146, 519530 .

\section{NEURONS AND GENES INVOLVED IN CHE- MICAL SENSITIVITY IN NEMATODES}

BAZZICALUPO P.*, HILLIARD M., LEWIS E.*, DE RISO L., SEBASTIANO M.*, RISTORATORE F.*

KEYWORDS : chemoreception. nematodes, behavior. avoidance, amphid.

\section{SUMMARY}

Organelles and neurons of nematodes involved in sensing chemical signals present in the environment are described. Laser ablation of neurons has helped assign them a specific function. Genetic mutational analysis has led to the identification of genes controlling the behaviour of the worms and/or some cellular properties of the

chemosensory neurons. Some conclusions on the general organization and functioning of chemoreception in nematodes can be drawn.

hemical signals from the environment are the most important sensory inputs for nematodes. The ability to receive and interpret chemical signals from the environment is essential for parasitic nematodes to find the host, complete their life cycle and reproduce. If better under-

\footnotetext{
* International Institute of Genetics and Biophysics, CNR, via G. Marconi 10, 80125 Napoli, Italy.
} 